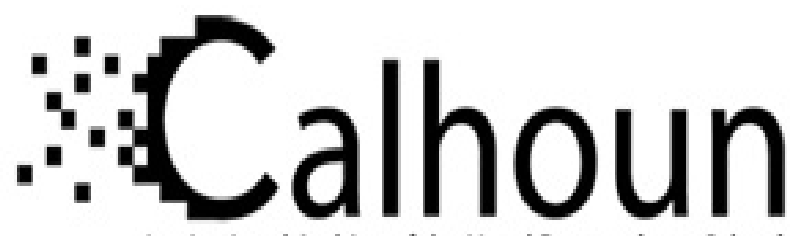

Institutional Archive of the Naval Postgraduate School

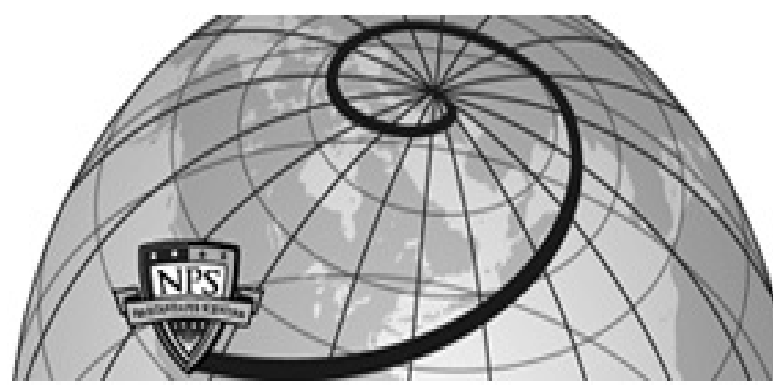

Calhoun: The NPS Institutional Archive

DSpace Repository

The Social Impact of the Defense Sector: How

Defense Sector Efforts Contribute to

Education and Quality of Health in

Disadvantaged Regions in Serbia

Anguelov, Lachezar G.; Eger, Robert J.

Political and Military Sociology: An Annual Review. 2013, Vol. 41: 19-40

https://hdl.handle.net/10945/46099

This publication is a work of the U.S. Government as defined in Title 17, United

States Code, Section 101. Copyright protection is not available for this work in the United States.

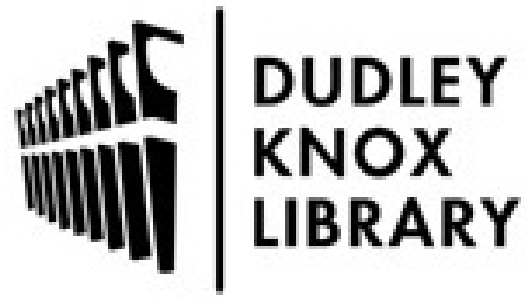

http://www.nps.edu/library
Calhoun is the Naval Postgraduate School's public access digital repository for research materials and institutional publications created by the NPS community. Calhoun is named for Professor of Mathematics Guy K. Calhoun, NPS's first appointed -- and published -- scholarly author.

Dudley Knox Library / Naval Postgraduate School 411 Dyer Road / 1 University Circle Monterey, California USA 93943 


\title{
The Social Impact of the Defense Sector: How Defense Sector Efforts Contribute to Education and Quality of Health in Disadvantaged Regions in Serbia
}

\author{
Lachezar G. Anguelov \\ Florida State University \\ Robert J. Eger III \\ Naval Postgraduate School
}

Political and Military Sociology: An Annual Review, 2013, Vol. 41: 19-40.

This article depicts the impact of military programs on education and improvements in the health of disadvantaged regions in the Republic of Serbia. Examining the reform efforts of the Ministry of Defense, we explore the presence of organizational coalitions, overlapping social movement, shared personnel, and broader changes to the external environment in implemented programs. A survey of the Ministry of Defense's Odbrana from 2007 indicates that "life after uniform" is facilitated through training in regional technical schools according to labor market needs. The survey also shows that military-provided health-care programs in southeast Serbia positively affect the quality of health in disadvantaged regions.

\section{Introduction}

The military institution is often said to have played a central role in the breakup of the Yugoslav state (Gow 2002; Karabelias 2003) and is currently being reformed to be an effective defense system in a region that is yet to be stabilized (Strategic Planning Department 2010). 
The reform efforts of the Serbian Ministry of Defense (MoD) are particularly important because MoD analyses are deemed to be an excellent starting point for those concerned with aspects of civil-military relations in other nations (Weeks 2003). Much of the literature emphasizes the civil control over the "political, social and economic" military institution, while the present study is concerned with the social impact of the defense sector and the effects of defense spillovers. Such concerns are encompassed within the definition of civil-military relations (Cottey et al. 2002).

The relations between defense and economic growth (Heo 1996; Heo 1998; Knight, Loayza, and Villanueva 1996; Mintz and Huang 1990) are prevalent in studies, with scholars depicting the importance of the defense sector for human capital and educational spillovers (Benoit 1973). Civil-military cooperation through shared instruction programs has been examined in instances in which partisan tendencies might be present (Watts 2002), which could be of particular importance for former Communist nations where "programs of political education and socialization within the military units" create high congruence between military elites and party leaders (Albright 1980:560). Nonetheless, the existing defense-sector social programs' spillover effect on society at-large has been an elusive endeavor.

In this article we focus on examining the reform efforts of the MoD of the Republic of Serbia, exploring the spillover effects of the military. We depict the impact of spillovers of military programs to education and improvements in health and quality of life in disadvantaged regions.

\section{Defense Planning in Serbia}

The Republic of Serbia, as an independent state, developed and adopted strategic-doctrinal and legal-normative documents in 2010. The reforms envisioned a modern Serbian Armed Forces integrated into a collective security system in which professionalization along with reforms to military education and military health care would allow the nation to "take a seat at the table with the countries and organizations to which we seek to become member, as it will make a contribution to the efforts to transform the Republic of Serbia from a user to an exporter of security" (Strategic Planning Department 2010:5).

In many transitional countries, the demands to build armed forces that are subjected to democratic controls and prepared for Euro-Atlantic integration have caused a number of radical changes in civil-military relations (Zrnić 2008). Serbia is often considered to be at least ten 
years in arrears in the development of such reforms due to a turbulent political environment and armed conflicts lasting up to the dawn of the new millennium. Even though security-sector reform in the Republic of Serbia started after the democratic changes of October 2000 (Zrnic 2008), developments regarding the independence of Montenegro and Kosovo have redefined the borders and policies of the republic. prolonging defense-planning reforms.

The adoption of laws and regulations concerning defense planning are an initial step required for the undertaking of further improvements of the defense system as a whole. In this particular case, only the MoD was vested with the primary task of defense reform. The MoD took steps to develop the basic strategic documents, and, during a session of the National Assembly of the Republic of Serbia on October 26, 2009, the National Security Strategy of the Republic of Serbia and the Defense Strategy of the Republic of Serbia were adopted. These initiatives and the processes of creating a normative framework were first adopted in November 2004, followed by the publication of the White Paper in 2005 (Zrnic 2008); however, the declarations of independence of Montenegro and Kosovo redefined the Serbian state, delaying the development of this framework.

One of the challenges of reform has been the lack of an adequate normative framework and unclear mechanisms to translate defense policy and long-term objectives into readily implementable plans (Zrnić 2008). To tackle this deficiency, novel organizations, such as the budget and finance sector, were founded in 2010 to establish and implement programs under the financial plans, as mandated by the MoD. In addition, a military health department was formed as a separate internal unit of the MoD to raise the efficiency levels of military medical institutions. Moreover, a public relations department was vested with promotional and educational objectives through various media sources.

The organizational chart for the public relations department is provided in Figure 1. The reforms undertaken indicate an acknowledgment that novel approaches to military proficiency should be directed not only toward defense of the state but should also include the vital support of civilian structures (Strategic Planning Department 2010). The training and education of troops would require an increase in resources, since the successful completion of this task is said to be more complex. Relying on better prepared human capital would benefit the MoD-hence, the desire for spillover of military programs to society in general. Professionalization of the military requires "training for the duty, testing of 
competences, retraining and acquiring of knowledge" of candidates who "have completed their national service, are involved in voluntary military training, or civilians who have not completed any military training" (Strategic Planning Department 2010:87).

Figure 1

Organizational Chart of the Public Relations Department of Serbia's Military of Defense

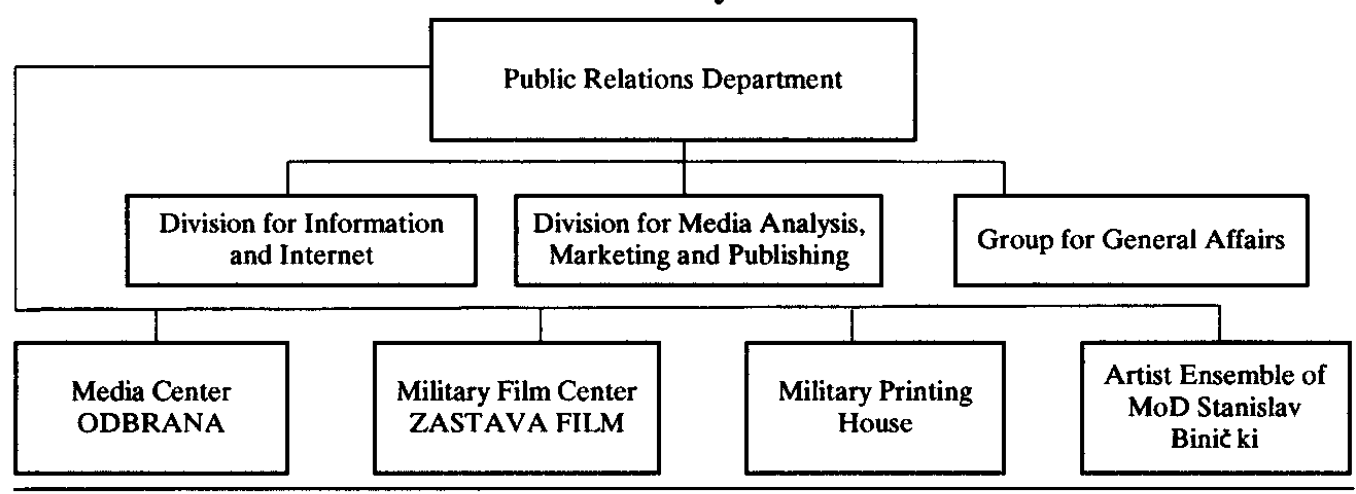

Source: Republic of Serbia Ministry of Defense'.

The newest organizational unit of the General Staff is the Civil-Military Cooperation Section (J-9), which, since 2006, has been responsible for activities that address the coordination between the armed forces and civilians in the field (Strategic Planning Department 2010). A CivilMilitary Coordination office was created in Vranje in June 2007 and has been responsible for joint exercises (civil-military) aimed at responding to various crises (Wall et al. 2008). A number of these actions have required regional cooperation with neighboring nations, allowing Serbian civilians to engage in coordinating learning initiatives. "The human factor remains the most important resource of the defense system of the Republic of Serbia" (Strategic Planning Department 2010:87). Thus, a critical imperative is to make employment in the military sector attractive to qualified personnel. An important aspect of fulfilling this task is legislative reform in the areas of education and personnel training, while aiming to improve the living standards of members of the armed forces. The adoption of modern scientific principles and the drive for education reform by the MoD are significant because a number of international reports cite education reform as a barrier for Serbia's accession into the European Union (European Commission 2010; European Integration Office 2011). Serbia's military has a longstanding, prestigious tradition in much of society, indicating that its emphases on education improvements are likely to spill over to society. The new initiatives strive to make careers 
in the Serbian Armed Forces (SAF) attractive and highly desirable by assuring support to the families of professional members "in their daily lives and preparation of professional members of the MoD and SAF for civilian life, after termination of professional services" (Strategic Planning Department 2010:88). Furthermore, training for the career changes of military personnel and training required for satisfactory performance of certain activities in the civil sphere are provided. At the time of publication, the White Paper indicates that a total of 1,569 persons have successfully completed the training program.

The development of multidimensional civil-military cooperation is a central objective for the defense sector, and it is suggested that the SAF are present in all activities of society on a daily basis (Strategic Planning Department 2010). A contributor to the development of such a successful relationship and its associated spillover to the rest of society is the "open and straightforward communication" that is achieved through the media that have "a significant and productive role in the democratic and civil control over the defense system" (Strategic Planning Department 2010:151). The Odbrana Media Centre, established in early 2010, is active in the distribution and publishing of information on issues of defense. It serves as a "promotional contact point of the $\mathrm{MoD}$, where all citizens showing interest in the defense system will be able to get all the necessary information regarding ... enrolling in the Military High School and Military Academy" (Strategic Planning Department 2010:158). Legislative reforms aid in this cooperation by establishing operations centers and offices where civil structures can access armed forces resources. Societal support is also provided by such initiatives as "Medical Doctor in the Country (Lekarnaselu)" and other humanitarian actions.

\section{Framework}

To depict how defense-sector programs spill over to society and to understand the impact of such spillover, evidence of the programs that are being implemented is essential. In addition, we should be able to observe a social impact (or no impact, if the programs do not effectively spill over) of the defense-sector and military program. Here, we seek to depict how resources including information, personnel, combat and utility equipment, as well as assistance, ${ }^{1}$ are engaged through defense-sector programs and affect society at-large. These resources can be tangible outcomes of a spillover process.

Theoretically, the relationship between expenditures in categories such as education, health care, and the defense sector should be analyzed 
carefully, because the military may provide "educational and medical care as well as vocational and technical specialties" (Benoit 1978:276). Therefore, if the military does provide such "spin-off, there would be a substantial role for the organized defense force in the developmental process" (Deger 1986:39). It is proposed here that military programs in Serbia affect society in two particular ways: (1) a reduction in the number of persons in the defense system (Strategic Planning Department 2010) requires programs focused on retraining for career change of redundant military personnel; and (2) competing for the most qualified (civilian) personnel arguably depletes other sectors of valuable human resources. Although the relationship between economic growth and the military sector is outside the theoretical scope of the present article, it is necessary that it be addressed, as it is fundamental for civil-military relations and the defense literature. McDonald and Eger (2010) indicate that there is no consensus on the relationship between defense spending and economic growth in the literature and that, in the cases of post-Soviet states, defense spending has promoted growth. In a number of transition countries, such as Serbia, this relationship may be of significant importance, as the percentage of GDP spent on defense fluctuates. At this particular time, such fluctuations appear insignificant to overall economic growth in Serbia. ${ }^{2}$ Nonetheless, as Ali (2011) indicates, in countries where the military-in addition to the state-provides social services through various programs, the relationship is further complicated. In Egypt, for example, the empirical results show that higher military spending results in lower spending on health and higher education.

Much of the literature covers the causal relationship between military spending and economic growth, but, ultimately, military programs exist in times of frugality as well as abundance. It is the purpose of this research, then, to direct attention to existing programs in an attempt to evaluate their effects on society in terms of education and health in disadvantaged regions. With the fluctuations of budgets (arguably, often driven by political rhetoric or the external environment), certain programs are eliminated (or expire) while others persist and can be labeled as "core programs." It is not our purpose to designate or categorize the initiatives as "core" or as alternatives, but to bring attention to the fact that we may not be able to adequately address how these programs affect society by extensively studying the relationship between growth and military expenditures. Arguably, this relationship will affect the peripheral programs but not the core, and the impact of such programs may not be readily visible at the national level. Thus we propose to study: (1) evidence of the existence of 
a particular program; $(2)$ how the program spills over to society at-large; and (3) what its measurable effects might be.

In order to analyze the existence, spillover, and the impact of programs, we will use the following theoretical arguments: Civil-military relations constitute a process (Watts 2002), and an analysis of the role of the MoD as an institution that mediates civil-military relations is warranted (Weeks 2003). As Weeks maintains, "Examining the Ministry of Defense provides an excellent starting point, since it is the primary political institution that is charged with coordinating many aspects of civil-military relations" (2003:24). The Serbian case appears consistent with the consensus that the "military is becoming more oriented to business and economic principles although still retaining substantial institutional features" (Siebold 2001:142). The civilian sector often receives the benefits of technology spillover. For example, a radar device developed under a U.S. Navy contract and then rejected for military use is being adapted for hospital use to monitor heartbeats without needing to be attached to the skin, making it particularly useful in therapy for burn victims (Heo 1998). A previous study has shown that discussions of political processes are important for developing a model of social movement spillovers (Meyer and Whittier 1994), and four important "routes of influence" are central to the processes: (1) organizational coalitions; (2) overlapping socialmovement community; (3) shared personnel; and (4) broader changes to the external environment. We propose that certain programs exist, that they are loosely defined as formal engagement of resources, and that they spill over to society through one or more of the above routes of influence.

Coalitions, defined as "structuring mechanisms that bring a broad spectrum of otherwise distinct organizations into contact" (Meyer and Whittier 1994:290), are important for the purpose of this study, especially in the areas of education and health care. The MoD's public relations department seeks to promote the defense-reform process and is responsible for disseminating information. The department achieves its promotional and educational objectives through "publishing, internet, video, film and television production, providing defense-related information to domestic and foreign media" (Strategic Planning Department 2010:32). In this way, the media center and its publishing activities are a forum that interacts with numerous stakeholders and distinct organizations. The social community route of influence calls for the production and distribution of promotional material that draws in participants, and Odbrana is actively engaged in this process. Examination of its publications reveals a widetargeted audience and a desire to be a forum for multiple participants. 
Odbrana is an institution within the public relations department, and its broad objective is informing the public about the operations of the defense sector. It provides interviews with top officials; detailed depictions of policy implementations and changes; information about events and specific army units; sections for world news, culture, spirituality, sports, jobs, and military housing and other advertisements. However, there are also sections that address education, health care, technology, and energy; thus, the center seeks to appeal to numerous participants from various spheres of civil society within the nation.

The shared personnel route is defined as important for inter-movement influences (Meyer and Whittier 1994) and is expected to be more significant in instances of common ideological and cultural settings. The introduction of new training systems aimed at interoperability will allow for professional soldiers to be selected from volunteers that have completed military service. It is further emphasized that respect for tradition is not to be overlooked, "and successful continuation of that tradition can be maintained through allowing young people to do their national service as volunteers, which will ensure a high reputation of the Armed Forces in society, and thus a good quality of the reserve troops" (Strategic Planning Department 2010:91). An important aspect of the new reforms of the $\mathrm{MoD}$ is the preparation of its members for civilian life after termination of their professional services, thus the possibilities for inter-movement influences are greatly increased. And finally, the broader changes to the external environment can be assessed as fluctuations in political opportunity structures that contribute to the processes responsible for the social impact of defense-sector initiatives.

A number of parameters can factor into situational changes, and some can be attributed to the external environment that affects the defense sector. These parameters range from geographic specifics, such as natural disasters, to international political climates. The defense sectors of many countries undertake social programs that focus on community health, education, and access to technology, but how those programs benefit the community is uncertain. By examining processes deemed important for the development of social spillover, we can account for how the spillover occurs and what its impact is. Focusing on the influences of organizational coalitions, overlapping community, shared personnel, and changes to the external environment is a theoretically appropriate means that brings us one step closer to fully depicting the spillover mechanism of defense sectors and its impact on society at-large. 


\section{Method and Data}

To determine the social spillovers of the defense sector, we seek evidence of social programs at work in Serbia's municipalities and compare the available data for differences in locations where such programs are not present. We believe that the use of Padilla and Laner's (2002) analyses of U.S. Army recruitment materials suit our research endeavor. We borrow the methodology that uses materials available in accessible archives (Padilla and Laner 2002). Whereas Padilla and Laner (2002) analyze print material, because it did not differ in terms of themes from its electronic counterpart, we are limited to available electronic materials; nonetheless, we presume that the above assumption about similarity of the content holds. Serbia's MoD has made one of its reform objectives the development of a successful model of relations between its citizenry and the defense sector. To do so, it is suggested that open and straightforward communication is essential and that the media will have a significant and productive role in the development of the relationship. The Department of Civil-Military Cooperation (J-9) is responsible for the organization, planning, and control of civil-military cooperation through its operations centers and offices that facilitate interactions. These centers are established to provide locations and means for citizens and the civilian structures to interact with and acquire help from the armed forces. To support civil-military cooperation, a wide range of resources are utilized and documented in the publications of Odbrana.

We examine issues from 2007 and outline the evidence of the social programs at work as well as their location of implementation. Table 1, below, provides a summary of the number of issues per year for the 2007 to 2009 period and includes a list of content headings and frequency of appearance. For 2007 and 2008, the number of issues was 23, and news, interviews, and events are standard in all issues. Whereas technology and culture are not emphasized in every issue, nonetheless they are also rarely absent. For 2009 , there were only 19 issues available online. Education and health content headings were of interest to examine the documentation of various programs that were implemented. For 2007, in all issues of Odbrana, the number of headings with education content was eight; their health counterparts numbered four. The italicized numbers in parenthesis for 2008 and 2009 indicate a one-page promotional segment for either an educational or health-care entity (the Military High School and Military Medical Academy, in particular). 
Table 1

Odbrana Issues and Content Volume, 2007-2009

\begin{tabular}{ccccccccc}
\hline Year & Issues & News & Interviews & Events & Technology & Culture & Education & Health \\
\hline 2007 & 23 & 23 & 23 & 23 & 18 & 22 & 8 & 4 \\
2008 & 23 & 23 & 23 & 23 & 14 & 20 & 2 & $7(3)$ \\
2009 & $19 *$ & 19 & 19 & 19 & 12 & 16 & $3(6)$ & $3(7)$ \\
\hline
\end{tabular}

*Indicates four missing issues for the particular year.

( ) Number of specific promotional materials not classified as content headings.

We follow the literature, in particular Costanza et al. (2008), in which measurement of quality of life is shown to be highly variable, with diverse objective and subjective indicators across a range of disciplines and scales. Given our limited data from the former Yugoslav states, we measure quality of life as the change in both of our qualitative measures for education and health. For the purpose of this research, in addition to the analysis of available qualitative data through Odbrana's municipal indicators from the Statistical Office of the Republic of Serbia are included. In particular, human health indicators that document the total number of general practitioners, specialists, and specialists-in-training for the year of interest in the municipalities examined will be observed, in addition to the number of inhabitants per one physician. The number of higher school and university faculties for the year of interest, also provided by the Statistical Office of the Republic of Serbia, will be examined, along with total number of students, the number of budgetfinanced students, as well as the number of graduate students recorded for the two types of institutions. Data on registered university students are compiled through annual surveys of registered students and graduate students. Surveys of registered students relate to data of winter-term registration (during the academic year), and the survey of graduate students relates to the respective calendar year. Table 2 provides a list of the education data.

Table 2

List of Educational Indicators ${ }^{6}$

Higher schools and university faculties

Total schools

Students (all, budget financed)

Graduate students

Source: Statistical Office of the Republic of Serbia (2005, 2007-2010). 
The responsibility for the collection and dissemination of healthrelated statistics within the Republic of Serbia is the responsibility of the Dr. Milan Jovanovic Batut Institute of Public Health. Data on health-care institutions (e.g., organizational units, workers, and activities) are collected through annual reports for certain types of health services. The published data were compiled from health-care institutions in the Republic of Serbia (with the exceptions of Kosovo and Metohija) that are included in the Plan of Health Institutions network. Staff numbers are shown as of December 31 and are from the Serbia Statistical Office. Table 3, below, lists the quality of human health indicators that will be used for this analysis.

Table 3

Quality of Health in Disadvantaged Regions Data

Total physicians

General practitioners

Specialists

In specialist training

Number of inhabitants per physician

Source: Statistical Office of the Republic of Serbia (2005, 2007-2010).

\section{Education Analysis}

Education reform has been a focus of numerous international (as well as domestic) initiatives, such as the Organization for Security and Cooperation in Europe Mission and its joint discussions with the Military Academy at a conference co-organized by the Mission and the Military Academy, with the financial assistance of the Czech government. In issue 34 of Odbrana (2007), the accreditation of military educational institutions is addressed, and a focus is placed on the Law on Higher Education of Serbia. Articles 3 and 4, in particular, stress the importance of equal access and the need to increase the number of people with higher education. The publication stresses that military institutions that wish to be accredited will have to adhere to the law adopted by Parliament in 2005. This law signifies an attempt by the Serbian government to be fully integrated into the European Union, and it addresses a key concern that Serbia has yet to develop an overall strategy covering all levels of education (European Integration Office 2011:38). As the military institution seeks to remain an important factor in societal development, adherence 
to the law is imperative for strengthening its role in education, as well as its position domestically and internationally.

Issue 35 continued to emphasize education, and the Military Medical Academy (MMA) is presented as a national treasure equivalent to a "temple of science and medicine." In the interview segment of the publication, it is pointed out that the MMA is the fifth clinical research center in the country and a significant portion of its work involves the training of young staff. It is further suggested that this facility is to be one that citizens of Serbia, as either patients or students, can go to, and one that embraces the healthy competition of ideas. Most notably, Odbrana points out that participating in peacekeeping missions around the world is desirable, and that such training is also beneficial when disseminated at home as well. The topic of schooling is further emphasized in issue 37, where the School of National Defense is highlighted as an institution that serves to educate in the science of war but is also available for specialized studies for residents at-large. The next issue's topics section focuses on the roles of civilian personnel in the defense sector and the need to reduce the number of staff, as required by the introduction of reforms. This is an interesting dynamic insofar as previous research has focused on examining from where the military draws its personnel rather than accounting for where former military careerists end up (see Evans, Felson, and Land 1980). The topic is further examined in the subsequent issue, addressing "life after uniform," where job losses in the military sector are equated to the loss of a profession and, thus, require further occupational training.

It has been recommended that retraining in technical, mechanical, and information technology fields address labor market needs adequately. These recommendations came out of research by the Danish company New Insight and the MoD and were awarded recognition by the Belgrade Chamber of Commerce. The outcomes consist of teaching modules to be implemented in two technical schools in the city of Belgrade. The desired spillover effect ensures that the work of the center is successful in retraining former service members so they are employable by various companies and agencies. Due to the large number of people joining the labor market in light of the reforms, the provision of training to increase the probability of former service members finding new employment is necessary. Furthermore, it is also stressed that it is necessary to align legislation in the area of adult education to alleviate problems generated by the transition reforms of military programs. The training centers highlighted are located in the cities of Niš, Novi Sad, and Belgrade and provide training modules according to market labor research. Spillover 
effects in industry composition should be evident in these cities from nearby residents taking advantage of such opportunities.

The population for the city of Belgrade (including its 17 municipalities) was estimated at $1,611,333$ in 2007 and expected to reach $1,630,582$ by 2009; however, the estimates provided by the Serbian Statistical Office do not allow for demographic distinction. During the 2004-2005 school year, there were 19 higher schools ${ }^{3}$ and 53 university faculty schools with 3,682 and 7,124 graduate students respectively. During the 2006-2007 school year (the publication year of Odbrana issues surveyed), the number of higher schools in Belgrade increased to 32, while the number of university faculty schools rose to 69 . The percentage of students that are budget financed ${ }^{4}$ remains almost unchanged (roughly $25 \%$ in higher schools and $55 \%$ in university institutions). For the 2008-2009 academic year, the number of higher schools is 30 , while university faculty schools number 68 . However, the number of graduate students attending higher school nearly doubled from the pre-publication date of 2004-2005. The total number of graduate students in the higher schools is 6060 , representing nearly $25 \%$ of the total student population, whereas in 2004-2005 they represented only $12 \%$ of the total student population. At the university level, the total number of graduate students was $7 \%$ of the entire student body, but, in 2008-2009, graduate students nearly doubled as percentage of the student body to $13.6 \%$.

Novi Sad had only 4 higher schools in 2004-2005 and 13 university faculty schools, whereas, in 2008-2009, there was one less higher school and 7 additional university faculty schools. In 2004-2005, 64\% of students were budget financed at the university level, while only $16 \%$ were budget financed at the higher school level. During the 2008-2009 academic year, however, $46 \%$ of university students and $35 \%$ of students in higher schools were financed. The city of Niš had only one higher school in 2004-2005, which increased by two in 2008-2009, while the number of university faculty schools remained constant at 11 . Nonetheless, the budget financing of students remained largely unchanged for the two academic years.

These developments in education suggest that retraining of dismissed military personnel may be emphasized in a number of technical schools in these regions. Indeed, regional officials identified retraining programs with a focus on particular sectors that align programs with labor market needs. A cornerstone of the new reforms in the Serbian military organization has been to make the sector attractive to qualified personnel. This was to be achieved primarily through legislative reform, in addition to education and personnel training. A goal of these reforms 
has been to increase interest in employment opportunities but, at the same time, to restructure the military in a more economic and efficient manner. We could outline how the proposed Serbian military reforms are to affect society; however, measuring such an effect is subject to data limitations. Thus, we theorize that the spillover effect of retraining opportunities in higher and university faculty schools is present in the changes observed between 2004 to 2005 and 2008 to 2009 . We hypothesize that these educational opportunities will affect the quality of life of former military personnel due to their potential positive influence on disposable incomes commonly associated with advanced education, as well as the concomitant likelihood for advancement in the labor market for those with advanced education.

Educational expansion is individual centric, and, thus, it is ultimately important to examine the routes of reform influence to account for organizational coalitions, possible overlapping social communities, shared personnel, and broader changes to the external environment. If we define organizational coalitions as mechanisms that allow for a broad spectrum of distinct organizations to interact, Odbrana provides a possible platform for a multiple-stakeholder forum. Through Odbrana publications and community outreach promotions, the Odbrana Media Centre is used as depicted in the White Paper of Serbia - as a tool to bring distinct organizations into contact. Through this social community, promotional material is distributed, and this is where we can find evidence of the military program's spillover to society as a whole. Even though the issues surveyed for 2007 exhibit a high volume of content that addresses advancements in the areas of education, empirical data and evidence are not readily available for analysis. While it is suggested that retraining of former service members is guided by local labor market demands, it is not clear what the direct impact is. While we can outline how the spillover is to take place, without available survey data or personal interviews, we would not be able to account for its effect on society. Nonetheless, through organizational coalitions and the establishment of social communities, the military sector seeks to promote its functions and to become a desirable career choice for the most qualified personnel in the country, while, at the same time, ensuring that, after expiration of service, its members will be adequately prepared for civilian life.

We theorize that military programs spill over to society through shared personnel, coalitions, and overlapping communities. It is suggested that such inter-movement influences are likely to be more significant in instances in which a common ideological and cultural setting is present. 
Serbia provides the required setting in the localities of Belgrade, Novi Sad, and Niš, where, after the 2008 election, two parties dominated the representation of elected delegates to the assemblies of municipalities and towns in Belgrade and Novi Sad - the Serbian Radical Party and a coalition of the G17+ and Democratic (DS) parties. In the city of Niš, the Serbian Radical Party is dominant, with 35 elected representatives, and 12 from the Democratic Party. In addition, the cultural and ethnic composition of the localities is largely similar, with over $94 \%$ of the population in Belgrade and Niš being ethnic Serbian (2002 census), with a much more diverse Novi Sad, where $75 \%$ of the population is depicted as ethnically Serbian.

The final stream of influence, the external environment, provides for a region that is often depicted as unstable and conflict-prone. It is not surprising then that a large segment of the population would be enticed to place an emphasis on strengthening military capabilities. Although in an unstable and conflict-prone region, a number of joint exercises and activities are depicted as incentives for a military career, since it provides training with regional and global partners. These exercises provide the opportunity to acquire advanced expertise through travel and teamworkoriented joint ventures.

We note that military spillovers, observed at the individual and community levels, are present and affecting societal change in Serbia. These spillovers are seen in individual opportunity, through advancement in education, and at the societal level through coalitions and regional cooperation, in the form of joint exercises and organizational sharing of Odbrana publications and community-outreach promotions. We reason that these military spillovers enhance the quality of life through advancement in earning potential, cooperative behavior that can reduce conflict and similarity in knowledge, and community action. which enhances community collective behavior.

\section{Quality of Health Analysis}

One of the internal units of the Ministry of Defense is the Military Health Department, formed in 2010 and responsible for "organization and provision of education, training and development of professional medical workers" (Strategic Planning Department 2010:32). The creation of the department is said to contribute to a more efficient management of military medical institutions. In issue 33 of Odbrana (2007), the military hospital in the city of Niš is noted as one of the oldest in the region, and it is suggested that measures are being taken to ensure that the facility displays all the characteristics of modern health-care institutions. It is 
also stressed that this is of importance to the Serbian army. The city of Niš houses many of the doctors and specialists in the area: out of the 1,573 physicians in the district, 1,364 are located in this municipality. This condensing of medical personnel leads to about 187 inhabitants per physician in Niš, a low number when compared to the neighboring municipalities within the district. Gadžin Han, with 426 inhabitants per physician, has the second smallest number of inhabitants per physician. Additionally, Gadžin Han has only 12 specialists, where the city of Niš has about 100 times that number.

The Military Medical Academy (MMA) has a long history. Often traced to the Decree of 1844 establishing the first "central Military hospital," by 1909 it was the most modern medical institution in the Balkans (Strategic Planning Department 2010:95). In a 2007 Odbrana interview (issue 35), it is pointed out that MMA is a leader in science and medicine and has a significant focus on training young staff. A sentiment expressed in this interview was MMA's openness to negotiation and compromise in order to achieve a functioning health system for the country. Training of its medical experts for peacekeeping missions around the world was also promoted as a benefit, as was its cooperation with colleges in Serbia. In particular, universities from the cities of Kruševac, Niš, and Novi Sad, as well as from Kosovo, were listed as active institutions in cooperative endeavors with the MMA.

There is no denying that the MMA and its numerous divisions have contributed to the development of medical science and research in the country. MMA employs nearly 3,000 individuals and participates in numerous multinational exchanges, and more than 50 of its young professionals have been sent to some of the world's best training centers (Strategic Planning Department 2010). It is also emphasized that military medical training exercises aimed at raising combat and technical readiness of its members have resulted in special recognition and popularity (Strategic Planning Department 2010). Thus, the MMA provides for organizational coalitions in which numerous establishments and participants can share a forum and exchange ideas as well as training in pursuit of scientific research and medical advancements. Thus, the MMA presence enhances coalitions that further the capacity of health benefits to the country's regions, with a high prominence in affecting the regional inhabitants' quality of life.

The multidimensional civil-military cooperation suggests that the Serbian Armed Forces deal with a wide range of social activities (Strategic Planning Department 2010). This is most evident when they have provided support to citizens in the aftermath of natural disasters. 
Additionally, provision of medical care to sick and disabled persons through organized action, such as "Medical Doctor in the Country (Lekarnaselu)," road maintenance in remote areas, and ensuring the water supply are other examples of humanitarian action that benefit society through the military structure. Such military efforts to improve the quality of health and life in disadvantaged regions are depicted in greater detail in Odbrana's issues. In issue 46, for example, we see the Garrison Command and the Office for Civil-Military Cooperation in the city of Vranje in action. The issue describes the launch of an initiative that provides free medical services in the localities of Preševo and Bujanovac. The Pčinja District, where these municipalities are located, is one of the most disadvantaged regions in Serbia, with an employment rate of only $22.4 \%$, and female employment at about $40 \%$ in 2004. In Bujanovac and Preševo, these figures are significantly lower, with overall employment rates of $15 \%$ and $1 \%$, respectively, and the percent of female employees at $33.8 \%$ and $24.1 \%$, respectively. In 2004 the number of inhabitants per physician in Bujanovac was 927, while in Preševo there were 1.199 inhabitants per physician (for the district this figure is 429 inhabitants). The 2005 numbers are similar, with Bujanovac and Preševo having, respectively, 880 and 1,114 inhabitants per physician.

In Table 4, we show the number of inhabitants per physician in the Pčinja District. It can be observed that from 2004 to 2009, Bosilegrad, Vranje, Surdulica, and Bujanovac do not change substantially with respect to the ratio of inhabitants per physicians. In particular, changes after the publication of Odbrana 2007-in which the defense sector efforts are outlined in detail-are relatively negligible for all municipalities except Preševo (program implemented) and Trgovište (program not implemented).

Table 4

Inhabitants per Physician in the Pčinja District, 2004-2009

\begin{tabular}{lrrrrrr}
\hline Municipality & $\mathbf{2 0 0 4}$ & $\mathbf{2 0 0 5}$ & $\mathbf{2 0 0 6}$ & $\mathbf{2 0 0 7}$ & $\mathbf{2 0 0 8}$ & $\mathbf{2 0 0 9}$ \\
\hline Bosilegrad & 629 & 576 & 561 & 547 & 535 & 559 \\
Bujanovac & 927 & 880 & 867 & 807 & 823 & 825 \\
Vladicin Han & 831 & 796 & 673 & 666 & 678 & 651 \\
Vranje - city & 268 & 281 & 285 & 281 & 280 & 280 \\
PreSevo & 1199 & 1114 & 1037 & 1022 & 855 & 865 \\
Surdulica & 262 & 269 & 262 & 249 & 246 & 240 \\
Trgoviste & 1515 & 1489 & 1946 & 1138 & 615 & 601 \\
\hline
\end{tabular}

Source: Statistical Office of the Republic of Serbia (2005, 2007-2010). 
Theoretically, population change can account for some of the fluctuation. In the case of Trgovište, where we see the most dramatic reduction in the post-2007 period, the population also decreased, in addition to the number of physicians almost doubling (from 5 in 2007 to 9 in 2009). In Preševo, the population actually steadily increased every year, and the number in physicians from 2007 to 2009 went from 38 to 46, with the addition of 2 specialists and 6 specialists-in-training. The narrative provided in the Odbrana issue depicts military medical teams visiting the mountain villages to perform medical examinations and provide essential drugs to the local population. Examples of military actions that improved the quality of life of the residents include a 1.1-mile-deep well to provide water, cleaning of the roads to improve accessibility, and the military engineering corps building a 6-kilometer-long water network system. In addition, local government leaders fully cooperated with the army initiative to implement the programs in such disadvantaged regions. This is important, since the general belief is that such undertakings will further strengthen cooperation between the army and the Albanian and non-Albanian populations in southern Serbia (the municipalities of Trgovište and Preševo have a majority Albanian population). The observed spillover in this example exemplifies civil-military cooperation.

In issue 51 of Odbrana, civil-military cooperation in southern Serbia is featured once again, and the Vranje Garrison Command and the Office for Civil-Military Cooperation of the Fourth Brigade of the Army are presented as continuing the campaign for delivery of free medical services and water supply to the villages in the Bujanovac and Preševo municipalities. Issue 52 also features an article in the "Training" section that outlines efficient risk response training for soldiers in civilian-military service that was conducted from October 4 to November 15, 2007, and was considered a significant contribution to the Organization for Assistance and Rescue and Civil Protection System.

\section{Conclusion}

In a number of countries around the world. the role of the military is becoming less institutional in nature and more occupational. In this study, we explored this trend in the Republic of Serbia, one of many countries reforming its military institutions and programs. In 2009, the Serbian Armed Forces and the Ministry of Defense introduced the System of Planning. Programming, Budgeting, and Execution in an effort to restructure and update practices and to strengthen multilateral co-operations with their neighbors and international organizations. As 
a consequence, a number of issues, including an increase in personnel joining the civilian sector, had to be addressed with various training programs through an increased emphasis on education. A survey of Odbrana publications reveals a desire to promote the educational institutions in the Republic of Serbia as well as to reiterate their strong tradition and historical importance.

The establishment of a public relations department within the Ministry of Defense provided for the creation of organizational coalitions and overlapping social movements that affect the educational sector in Serbia. A number of the issues surveyed provided promotional information and indicated shared personnel initiatives that are possible routes of influence in the spillover of defense-sector programs. The novelty of reforms and programs makes it difficult to directly evaluate the impact of potential spillovers in the area of education; nonetheless, we observed the desire for improvements in this fundamental area. We noted the transitional change through measuring the advancement of educational opportunities and institutional increases. We theoretically posit that the increase in the number of individuals seeking advanced education is a function of the change in the military's institutional outreach in Serbia, providing an opportunity for an increase in the individual and regional quality of life through the potential of increased disposable income as well as the opportunity offered in advanced educational training in the labor market.

The issues of Odbrana that we surveyed outlined broader changes to the external environment in their dissemination of information. Improvements were sought in the quality of health in disadvantaged regions within the country, and the public relations department actively documents military initiatives that affect such regional change. The provision of medical care in southeast Serbia through "Medical Doctor in the Country (Lekarnaselu)" is an example of a military program that affects society at-large. Through this initiative, we observed a reduction in the total number of inhabitants per physician in a municipality in which the program was implemented, whereas the ratios in neighboring municipalities remain unchanged in the period after implementation. The impact of this program, small as it may be, provides evidence of spillover that improves the quality of health care in the targeted region and is evident-not only in the narrative of Odbrana issues that depict military medical teams visiting mountain villages to provide services and essential drugs to local populations-but also in the documented indicators of the number of inhabitants per physician in the targeted municipalities. 
Further actions documented in the issues surveyed show that programs were implemented to improve accessibility through road maintenance, sanitation, and improvements in water network systems. Although these impacts could not be measured, we suggest that these actions, through the cooperation of the military and local governments, enhance the quality of life for those affected, while increasing spillover effects of cooperative behavior. Further research could contribute to the literature by creating appropriate measures of these and other similar initiatives at the local level or by conducting detailed interviews and field observations in order to depict the spillover and its impact, as suggested by our findings. The goal of this article has been to depict how defense-sector programs spill over to society and to document the impact of such spillover. To do so we sought evidence of programs being implemented and evaluated potential measurable outputs and indicators available through the Municipalities of Serbia catalogues available through the Statistical Office of the Republic of Serbia.

\section{Notes}

1. Assistance here is defined as the involvement of military and nonmilitary personnel in civil-military cooperation for the purpose of assisting the civilian population (Strategic Planning Department 2010).

2. The percentage of GDP spent on defense in Serbia remains almost constant from 2010 to 2013, at levels of 2.1 to $2.4 \%$. In particular, projected estimates for 2012 are $2.2 \%$ and for 2013 are $2.4 \%$.

3. Higher schools are classified as colleges of applied sciences (visoka škola strukovnih studija) and colleges of academic studies (visoka škola).

4. A higher education institution instituted by the state that receives funds for the implementation of approved and/or accredited study programs on the basis of a contract between the independent higher education institution and the state. In practice, the funds are transferred directly from the state budget to the faculties (European Commission 2010).

5. http://www.mod.gov.rs/eng/organizacija/odnosi_sa_javnoscu/odnosi_sa_javnoscu.php

6. In the statistics of education section, the Statistical Office of the Republic of Serbia categorizes schools as organizations or composite units engaged in teaching activity pursuant to defined study programs and curriculum regardless of whether they are independent schools, regional divisions, or separate forms within schools of another type.

\section{References}

Albright, David E. 1980. "A Comparative Conceptualization of Civil-Military Relations." World Politics 32(4):553-576.

Ali, Hamid E. 2011. "Military Expenditures and Human Development: Guns and Butter Arguments Revisited: A Case Study from Egypt." Peace Economics, Peace Science and Public Policy 17(1):1-19.

Benoit, Emile. 1973. Defense and Economic Growth in Developing Countries. Lexington, MA: Lexington Books. 
Benoit, Emile. 1978. "Growth and Defense in Developing Countries." Economic Development and Cultural Change 26(2):271-280.

Costanza, Robert, Brendan Fisher, Saleem Ali, Caroline Beer, Lynne Bond, Roelof Boumans, Nicholas L. Danigelis, Jennifer Dickinson, Carolyn Elliott, Joshua Farley, Diane Elliott Gayer, Linda MacDonald Glenn. Thomas R. Hudspeth, Dennis F. Mahoney, Laurence McCahill, Barbara McIntosh, Brian Reed, Abu Turab Rizvi, Donna M. Rizzo, Thomas Simpatico, and Robert Snapp. 2008. "An Integrative Approach to Quality of Life Measurement Research and Policy." Surveys and Perspectives Integrating Environment and Society. Retrieved August 1, 2012 (http://www. surv-perspect-integr-environ-soc.net/1/11/2008/sapiens-1-11-2008.pdf).

Cottey, Andrew, Timothy Edmunds, and Anthony Forster. 2002. Democratic Control of the Military in Postcommunist Europe: Guarding the Guards. New York, NY: Palgrave Publishers Ltd.

Deger, Saadet. 1986. Military Expenditures in Third World Countries: The Economic Effects. London, UK: Routledge and Kegan Paul.

European Commission. 2010. Serbia 2010 Progress Report. Brussels: European Commission. Retrieved December 1. 2011 (http://ec.europa.eu/enlargement/pdf/ key_documents/2010/package/sr_rapport_2010_en.pdf).

European Integration Office. 2011. Action Plan for Fulfillment of Priorities under the European Commission 2010 Progress Report, with the Aim of Accelerating the Achievement of Candidate Country Status. Belgrade: Republic of Serbia. Retrieved December 1, 2011 (http://www.seio.gov.rs/upload/documents/Vesti/!FINAL_ MASTER_AP_ProgressReport2010_EN.pdf).

Evans, M. D., Marcus Felson, and Kenneth C. Land. 1980. "Developing Social Indicators Research on the Military in American Society." Social Indicators Research $8(1): 81-102$.

Gow, James. 2002. "The European Exception: Civil-Military Relations in the Federal Republic of Yugoslavia (Serbia and Montenegro)." Pp.194-215 in Andrew Cotey, Timothy Edmunds, and Anthony Forster, eds. Democratic Control of the Military in Postcommunist Europe: Guarding the Guards. New York, NY: Palgrave Publishers Ltd.

Heo, Uk. 1996. "The Political Economy of Defense Spending in South Korea." Journal of Peace Research 33(4):483-490.

Heo, Uk. 1998. "Modeling the Defense-Growth Relationship around the Globe." The Journal of Conflict Resolution 42(5):637-657.

Karabelias, Gerassimos. 2003. "A Brief Overview of the Evolution of Civil-Military Relations in Albania, Greece, and Turkey during the Post-WWII Period." Journal of Political and Military Sociology 31(1):57-70.

Knight, Malcolm, Norman Loayza, and Delano Villanueva. 1996. "The Peace Dividend: Military Expenditure Cuts and Economic Growth." IMF Staff Papers 43(1):37-43.

McDonald, Bruce D. and Robert J. Eger III. 2010. "The Defense-Growth Paradigm: An Economic Investigation into Post-Soviet States." Peace Economics, Peace Science and Public Policy 16(5):1-26.

Meyer, David S. and Nancy Whittier. 1994. "Social Movement Spillover." Social Problems 41(2):277-298.Mintz, Alex and Chi Huang. 1990. "Defense Expenditures, Economic Growth and the 'Peace Dividend." American Political Science Review 84(4): 1283-93.

Odbrana Media Centre. 2007. "Archive of Одбрана magazine: Issues 31-54." Ministry of Defence. Retrieved November 13, 2011 (http://www.odbrana.mod.gov.rs/arhiva. php?godina $=2007 \&$ id_casopisa $=1)$.

Padilla, Peter A. and Mary Riege Laner. 2002. "Trends in Military Influences on Army Recruitment Themes: 1954-1990."Journal of Political and Military Sociology 30(1):113-133. 
Siebold, Guy L. 2001. "Core Issues and Theory in Military Sociology." Journal of Political and Military Sociology 29(1):140-159.

Statistical Office of the Republic of Serbia. 2005. "Municipalities and Regions of the Republic of Serbia." Republic of Serbia. Retrieved December 1, 2011 (http://pod2. stat.gov.rs/ObjavljenePublikacije/G2005/pdfE/G20052002.pdf).

Statistical Office of the Republic of Serbia. 2007. "Municipalities and Regions of the Republic of Serbia." Republic of Serbia. Retrieved December 1, 2011 (http://pod2. stat.gov.rs/ObjavljenePublikacije/G2007/pdf/G20072001.pdf).

Statistical Office of the Republic of Serbia. 2008. "Municipalities and Regions of the Republic of Serbia." Republic of Serbia. Retrieved December 1, 2011 (http://pod2. stat.gov.rs/ObjavljenePublikacije/G2008/pdf/G20082001.pdf).

Statistical Office of the Republic of Serbia. 2009. "Municipalities and Regions of the Republic of Serbia." Republic of Serbia. Retrieved December 1, 2011 (http://pod2. stat.gov.rs/ObjavljenePublikacije/G2009/pdfE/G20092001.pdf).

Statistical Office of the Republic of Serbia. 2010. "Municipalities and Regions of the Republic of Serbia." Republic of Serbia. Retrieved December 1, 2011 (http://pod2. stat.gov.rs/ObjavljenePublikacije/G2010/pdfE/G20102003.pdf).

Strategic Planning Department. 2010. White Paper on Defense of the Republic of Serbia. Belgrade: Ministry of Defense.

Wall, Earl, Edward Chu, and Ivan Dimitrijevic. 2008. The Civil Protection System in Serbia. Jefferson Institute Publications. Retrieved November 12, 2011 (http://www. jeffersoninst.org/publications/civil-protection-system-serbia).

Watts, Larry L. 2002. "Reforming Civil-Military Relations in Post-Communist States: Civil Control vs. Democratic Control." Journal of Political and Military Sociology 30(1):51-70.

Weeks, Gregory. 2003. "Is the Mold Being Broken? Defense Ministries and Democracy in Latin America." Journal of Political and Military Sociology 31(1):23-37.

Zrnić, Bojan. 2008. "New Trends in Defense Planning and Their Impact on the Defense Planning Systems in Transition Countries." Vojno Delo 1(2008):25-38. 